\title{
舌および頸部食道重複癌の再建術
}

*浅野 勝士, 土居 保幸, ${ }^{* *}$ 西尾 正道
桜井 智康, 村上 義敬, ${ }^{* * *}$ 晴山 雅人
${ }^{* * * *}$ 保立 武雄, ${ }^{* * * * *}$ 形浦 ${ }^{\text {昭克 }}$

\section{Reconstructive Surgery in a Patient with Double Cancer of the Tongue and Cervical Esophagus}

Katsuji Asano, M.D. and Yasuyuki Doi, M.D.

Department of Otorhinolaryngology, Tonan Hospital, Sapporo

Masamichi Nishio, M.D., Tomoyasu Sakurai, M.D. and Yoshitaka Murakami, M.D.

Department of Radiology, Hokkaido Cancer Center Hospital, Sapporo

Masato Hareyama, M.D.

Department of Radiology, Sapporo Medical College, Sapporo

Takeo Hotate, M.D.

Department of Otorhinolaryngology, Hakodate Goryokaku Hospital, Hakodate

Akikatu Kataura, M.D.

Department of Otorhinolaryngology, Sapporo Medical College, Sapporo

We had a patient with cancers of the tongue and the cervical esophagus. Cancers were resected and the defect in the oral cavity was primarily reconstructed with the use of PM-MC flap, and a free flap from the radial forearm was used for the reconstruction of the cervical esophagus by microvascular surgery.

We consider that the radial forearm free flap is useful for the reconstruction of the cervical esophagus.

Key words : double cancer, radial forearm flap

はじめに

頭頸部領域の重複癌は必ずしも稀な疾患では ないが，一期的手術により治療する機会は少な い。重複癌発生の増加もさることながら頭頸部 領域は, 構造上同一の管腔構造と近似した組織 学的形態を有し，飲酒あるいは喫煙などの外的 刺激因子に一様に暴露され得ることが, 頭頸部 領域の重複癌とくに食道癌との重複が増加して いる原因と考えられる ${ }^{1223344}$ 。
頭頸部癌が食道癌と重複する場合には同時重 複あるいは頭頸部癌が先行して比較的短期間に 食道癌が発生する確率が高いとされているが5), 本症例も舌癌 $\left(\mathrm{T}_{3} \mathrm{~N}_{0} \mathrm{M}_{0}\right)$ 診断後 3 力月で頸部 食道癌 $\left(\mathrm{T}_{2} \mathrm{~N}_{1} \mathrm{M}_{0}\right)$ が診断された。この症例の ような同時重複癌を外科治療にて根治し得る機 会は重複癌の進展度, 患者自身の社会的背景お よび全身状態が障害となり非常に少ない。今回 われわれは舌, 喉頭および下咽頭頸部食道を摘
*斗南病院耳鼻咽喉科

**北海道がんセンター放射線科

$* * *$ 札幌医科大学放射線科
函館五稜郭病院耳鼻咽喉科

******札幌医科大学耳鼻咽喉科 


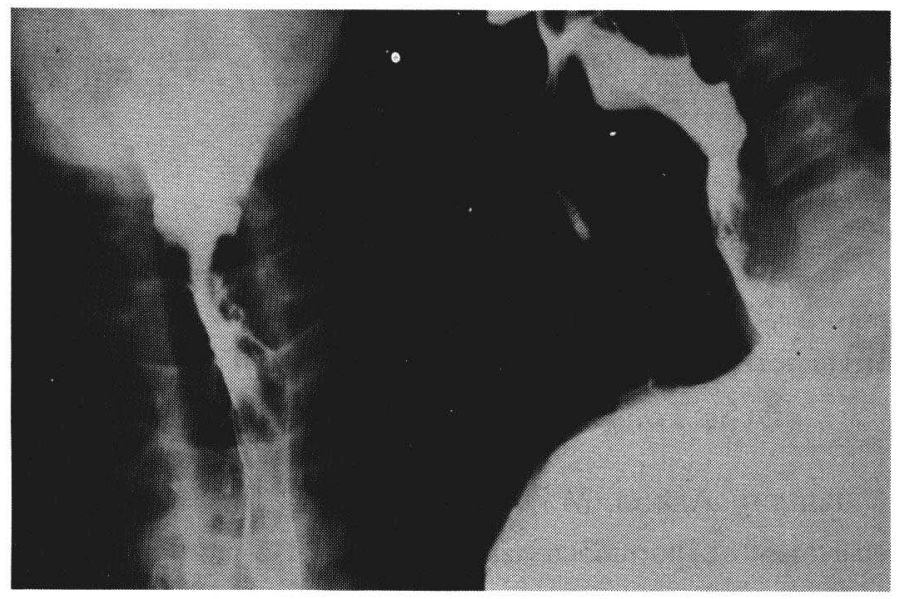

図 1 術前の頸部食道バリウム造影像。

出後, 有茎および遊離皮弁を用いて一期的に再 建し得たので報告する。

症例

患者：47歳 男性

舌癌 $\left(\mathrm{T}_{3} \mathrm{~T}_{0} \mathrm{M}_{0}\right)$ 高分化型扁平上皮癌 頸部食道癌 $\left(\mathrm{T}_{2} \mathrm{~N}_{1} \mathrm{M}_{0}\right)$ 低分化型扁平 上皮癌

主訴：舌痛および嚥下障害

既往歴：特記すべきことなし

家族歴：特記すべきことなし

生活歴：酒 5 合 $/$ 日，喫煙30本／日

現病歴：昭和 58 年 2 月初旬上り左舌縁に潰瘍 を伴った腫瘤を認め近医にて加療を受けるも軽 快せず 3 月24日国立札幌病院（北海道がんセン ター) 放射線科へ紹介された。

初診時所見は舌左側に長さ $4.7 \mathrm{~cm}$, 幅 $2.5 \mathrm{~cm}$ および高さ $2.7 \mathrm{~cm}$ の中央部に潰瘍を伴う腫瘤 を認めた。治療は放射線治療単独でおこない, Linac $(6 \mathrm{MeV})$ で $3000 \mathrm{rad}$ 外照射後 (昭和58年 3 月30日〜 4 月 19 日) に組織内照射 $5600 \mathrm{rad}$ (Cs needle implantation, biplane) を施行し， 5 月 25 日軽快退院した。6月16日第 1 回目の定期検 診にて嚥下障害を訴え, 食道バリウム透視にて 第 6 頸椎から第 2 胸椎に一致して狭窄像を認め た(図 1)。食道鏡下生検の結果は低分化型の扁 平上皮癌と診断されたが，再度の放射線治療を 患者が強く拒否したため5-FU (1000 mg/日) 投 与にて外来で経過観察および加療した。8月 1
日再入院し即日よりペプレオマイシン $(5 \mathrm{mg} \times$ 10回，2クール）投与と共に頸部食道に対して 外照射（T.D $4750 \mathrm{rad}$; 昭和58年 8 月 1 日〜 9 月 1 日) を施行した。同時期に舌癌の再発 $\left(\mathrm{rT}_{3}\right.$ $\mathrm{N}_{0} \mathrm{M}_{0}$, Stage III) も認められ重複癌に対する一 期的外科治療を目的として 9 月 29 日斗南病院耳 鼻咽喉科に転科した。入院時の諸検査では特記 すべき所見はなく，経口捸取不能の状態であっ たので胃管栄養と中心静脈栄養により 3000 $\mathrm{cal} /$ 日投与を開始した。

\section{手術および術後経過}

手術は舌癌が舌 $2 / 3$ まで広がり一部は舌根部 に達していることと, 頸部食道癌が $\mathrm{C}_{6} \sim \mathrm{Th}_{2}$ (図 1）まであることより, 舌・喉頭・下咽頭およ び頸部食道摘出を予定したが，再建に使用可能 な皮弁は広背筋皮弁 (LD-MC flap) と撓骨前腕 皮弁 (Forearm flap) の遊離移植が最適と思わ れた。10月21日安全を考えて DP 皮弁を作成し た後に, 左保存的頸部廓清術, 右根本的頸部廓 清術，胸骨縦切開による縦隔開創（第 4 肋骨ま で), 甲状腺全摘出および両側気管旁リンパ節廓 清術, 喉頭・下咽頭および頸部食道摘出術 $\left(\mathrm{C}_{3}\right.$ 〜 $\mathrm{Th}_{3}$ )を施行し, さらに下顎骨を正中離断し舌 全摘出術を施行した。再建に関して当初予定し た LD-MC flapまたは Forearm flapでは長さ に不安が生じたので口腔側は大胸筋皮弁 (PMMC flap) で再建し咽頭および食道側を Forearm flap で再建した。 


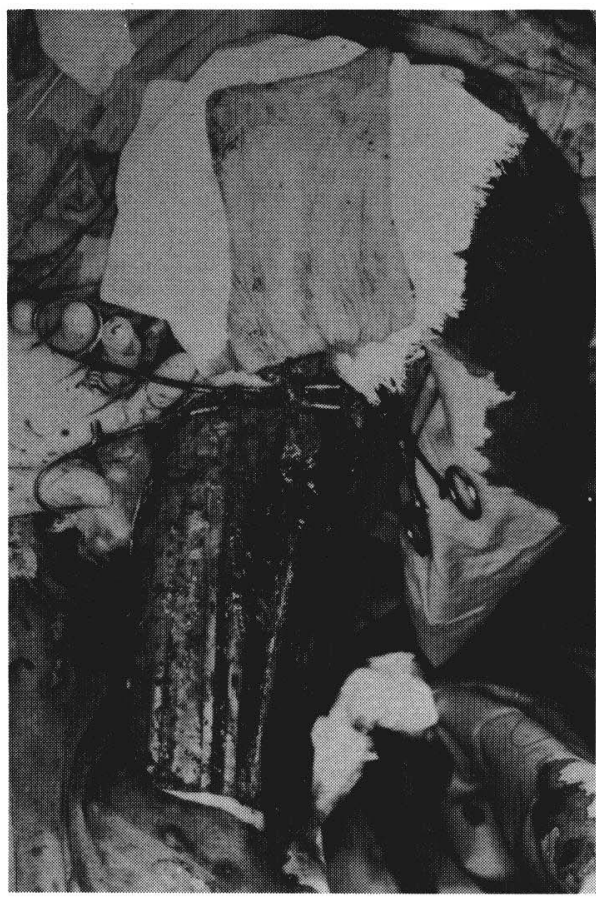

図 2 撓骨前腕皮弁作成状況と撓骨動静脈。

図 2 および図 3 は血管吻合を行なった 撓骨動脈と撓骨皮静脈および浅頸動脈と 外頸静脈である。血管吻合は術後止血剤 を使用しないこと以外には特別な処置は 不要であった。術後は低蛋白症 $(5.2 \mathrm{~g} / \mathrm{dl})$ を認めたほかは経過良好であったが，術 後 7 日目に PM-MC flap による口腔底 再建部に一部縫合不全を生じ，右側顎下 部に膿瘍形成を認めた。全麻下に右頸部 開創したところ吻合血管および Forearm flapに異常なく局所を清掃し て再縫合した。術後22日目に頸部食道の 通過状態をバリウム透視にて確認し（図 4 ) 経口攝取を開始したが, 舌全摘出と 下咽頭頸部食道摘出のために食物（流動 食）攝取の要領を知るのにさらに 2 週間 を要した。術後 2 カ月目に退院となった。 図 5 および図 6 は退院時の頸部と前腕の 状態である。前腕の機能障害は認めなか つた。

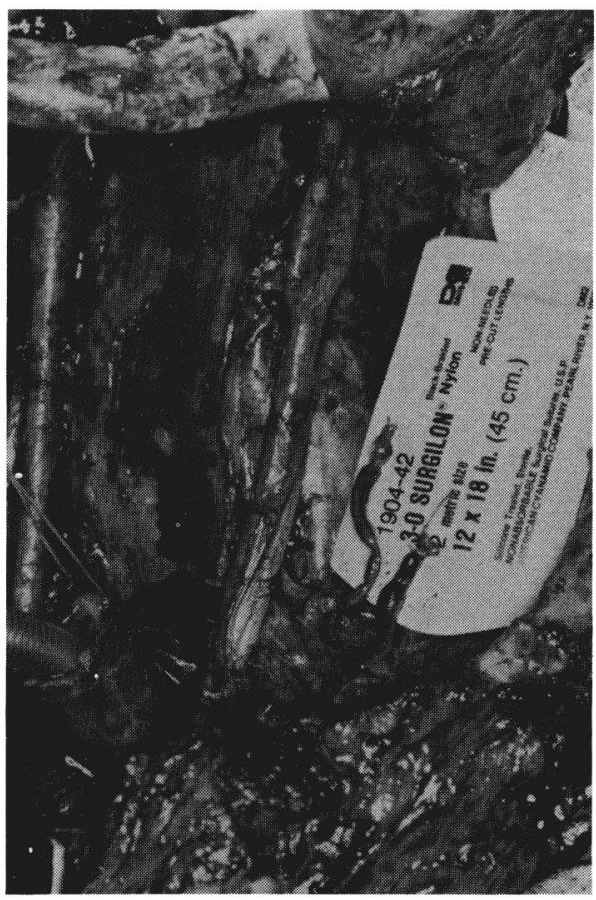

図 3 咽喉食摘術後の状況と血管吻合のため保存 した外頸静脈と浅頸動脈。

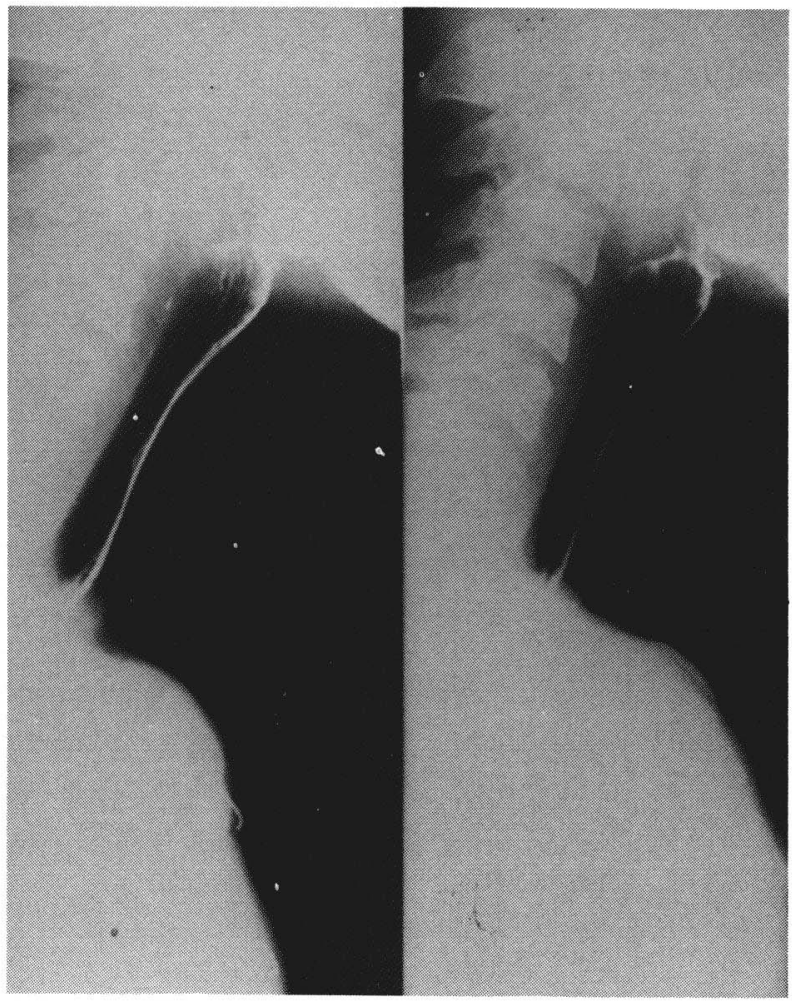

目 4 術後 3 週目の食道バリウム造影像。 


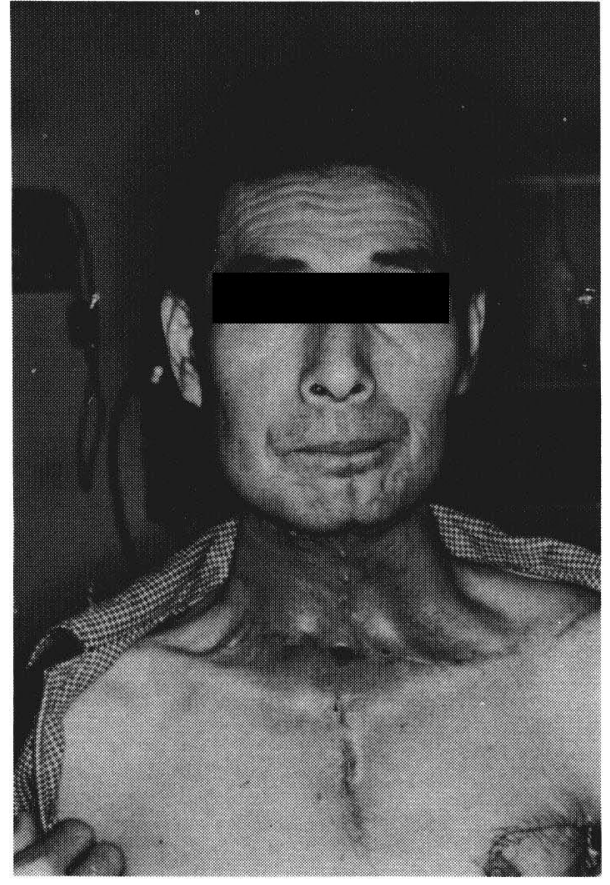

図 5 術後 2 力月経過した頸部術創。

\section{考察}

頭頸部癌の再建に関しては，1965年 Bakamjian が DP 皮弁を利用した再建方法を報告して 以来, 頭頸部癌における再建手術のために種々 の皮弁が応用されてきた ${ }^{6778)}$ 。これらの皮弁は頭 頸部癌に対する拡大手術を可能ならしめて，そ の治療成績向上に貢献してきたが, 同時に問題 点も指摘されてきた。すなわち DP 皮弁におい ては二期的手術となり経口摄取までに時間がか かり，とくに頸部食道癌によっては鎖骨切除を 要することであり, PM-MC flap では, 女性に 使用しづらいこと, 食道再建において食道側吻 合部に狭窄を生じやすいことなどである。

本症例において頸部食道再建に，1981年 Yangらによって報告された撓骨前腕皮弁9 ${ }^{1011112)}$ Forearm flapを用いた。Forearm flap は薄く，柔軟であり食道などの管腔を作成しゃ すいために使用した。この皮弁は採取時に撓骨 動脈と皮弁が剥離しないよう注意すれば安全に 採皮可能であり，術野の対側の上腕から採取す ることにより, 癌摘出術と並行して行なえ手術 時間を短縮でき，全身に対する手術侵襲も少な

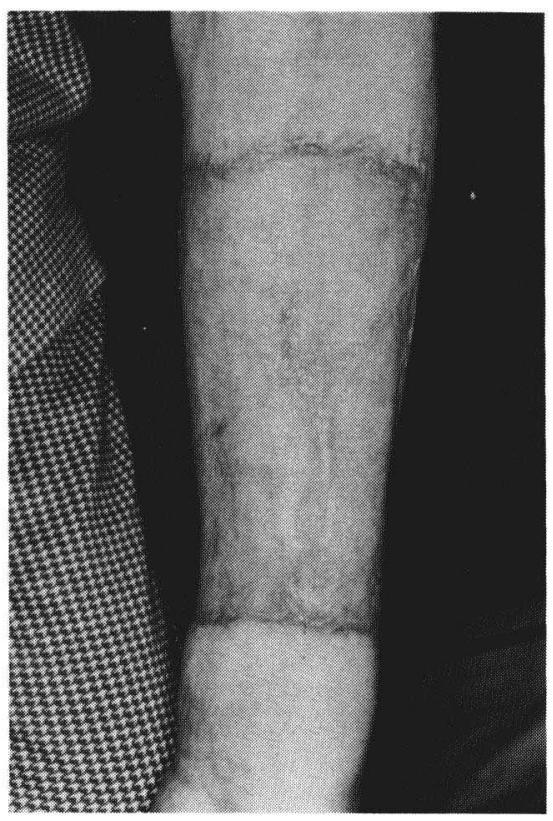

図 6 術後 2 力月経過した撓骨前腕皮 弁採取部位。中間層皮弁にて再建。

いなどの利点がある。血管吻合技術が発達して 安全で確実に行なわれている今日ではこれから 多く利用される皮弁と思われる。本症例に使用 した Forearm flap では長径 (門歯内側より $\mathrm{C}_{3}$ レベル) に不安が生じたため, 有茎の PM-MC flap を併用したが遊離の LD-MC flap によるひ とつの皮弁での再建の可能性はあるように思わ れる ${ }^{13)}$ 。しかしながら, 本症例のように重複癌で 舌を含めた上部消化管を切除した症例では，與 下機能が不可能なため, 流動物以外は摄取でき ず，癌を根治することも含め，機能面に関して も現在まだ外科治療が解決し得ない問題であ り,これからの癌治療の問題点のひとつでもあ ると思われた。

\section{まとめ}

舌癌 $\left(\mathrm{T}_{3} \mathrm{~N}_{0} \mathrm{M}_{0}\right)$ および頸部食道癌 $\left(\mathrm{T}_{2} \mathrm{~N}_{1} \mathrm{M}_{0}\right)$ の同時重複癌症例に対し有茎大胸筋皮弁と遊離 撓骨前腕皮弁を用い再建し，良好な結果を得た ので報告した。

終稿に臨み，技術的指導を賜った国立がんセンタ 一頭頸科, 海老原敏先生, 東京大学形成外科, 波利 


\section{井清紀先生に深謝致します。}

$$
\text { 文 献 }
$$

1) Warren, S., Gates, O.: Multiple primary malignant tumors, a survey of the literature and a statistical study. Am. J. Cancer, 16: 1358-1414, 1932.

2 ) Wynder, E.L., Mushinski, M.H., Spivak, J.C. : Tobacco and alcohol consumption in relation to the development of multiple primary cancer. Cancer, 37: 85-89, 1977.

3 ) Vrabec, D.P. : Multiple primary malignancies of the upper aerodigestive system. Ann. Otol., $88: 846-854,1979$.

4 ) 加賀美芳和, 桜井智康, 晴山雅人, 西尾正道, 酒勾健, 斉藤明男, 新島和也: 重複癌症例の検討, 癌の臨床， $26: 396-399,1980$.

5 ) 川本誠一, 池田治, 西山謹司, 宮田敏明, 真崎 規江, 重松康：頭頸部癌における重複癌一重複部 位・頻度など統計的考察一, 癌の臨床, $28: 1-7$, 1982.

6) Bakamjian, V.Y.: A tow-stage method for pharyngoesophageal reconstruction with a primary pectral skin flap. Plast. \& Reconstr. Surg., 36 : 173-184, 1965.

7 ) Ariyan, S.: The pectoralis major myocutaneous flap. A versatile flap for reconst- ruction in the head and neck. Plast. \& Reconstr. Surg., 63: 73-75, 1979.

8 ) 村上泰, 原口茂徳, 岡田康司, 安藤真姿子, 丸 山毅, 小掘正 : 大胸筋 myocutaneous island flap による頸部食道一期的再建術, 日気食会報, 31 ： 228-237, 1980.

9 ) Yang, G. et al. : Forearm free skin flap transplantation. National Medical Journal of China, $61:$ 139-141, 1981.

10) Soutar, D.S., Scheker, L.R., Tanner, N.S.B., Mcgregor, I.A.: The radial forearm flap: a versatile method for intra-oral reconstruction. Brit. J. Plast. Surg., 36 : 1-8, 1983.

11) Harii, K.: Microvascular tissue transfer. Igaku-shoin, Tokyo, New York, 1983.

12）高戸毅, 小野勇, 海老原敏, 斉藤裕夫, 吉積隆, 波利井清紀：Free forearm flap を用いた再建 術, 形成外科, $27: 464-469,1984$.

13）波利井清紀, 山田敦, 福田修: Myocutaneous flap の理論と応用, 形成外科, $22 ： 664-679,1979$.

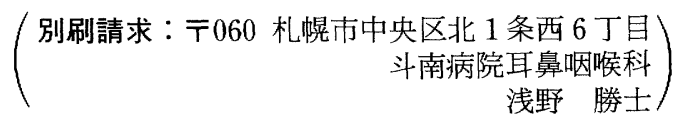

(投稿受付 1984 年 9 月 6 日) 